\title{
Care as Norm in French Schools
}

\author{
Sophie Devineau ${ }^{1}$ \\ ${ }^{1}$ PU, DySoLa, Université de Rouen, France \\ Correspondence: Sophie Devineau, Université de Rouen, France. E-mail: sophie.devineau@univ-rouen.fr
}

Received: April 15, 2015 Accepted: July 13, 2015 Online Published: August 14, 2015

doi:10.5539/res.v7n11p312 URL: http://dx.doi.org/10.5539/res.v7n11p312

\begin{abstract}
French female teachers seek to work at the first years of schooling and express an overwhelming preference for the nursery school. This longstanding gendered division of social roles in schools presents no sign of abating. We will explore here the underlying mechanisms of this conservative inertia. Women's preference for nursery schools will be addressed on the basis of "care" having become the norm in French schools and professional roles and teaching jobs being ascribed along a gendered hierarchy of teaching jobs.

We will then focus on the hurdles young women face when they enter the teaching profession and how balancing work and family is tantamount to "squaring the circle". We will look at the family environment in order to substantiate the pressure exerted on women so that they "put family first". Finally, we will explore how women try to solve this normative dilemma linked to their working lives. We will analyze the mechanisms that underlie their choices in the context of the general hostility of the world of work and the internal institutional mechanisms that operate in schools.
\end{abstract}

Keywords: gender, care, teachers, nursery school, occupational categories

\section{Introduction}

French female teachers seek to work at the first years of schooling and express an overwhelming preference for the nursery school. This longstanding gendered division of social roles in schools presents no sign of abating. I will explore here the underlying mechanisms of this conservative inertia. A previous study (Devineau, 2006) conducted on students aspiring to become primary school teachers brought to light the prevalence of gender role stereotypes. Gendered differences seem to imbue the young respondents' representations of both teaching and teacher training, even when attitudes were observed "all other things being equal". Clearly, gender differences seem to run through everything we studied, including the reasons why young people chose to become teachers, their preferences for teaching in elementary or secondary schools or their representations of future professional practice and career prospects. There is accordingly no doubt about the extent and the pervasiveness of these gendered representations.

I will first analyze why women's preference for nursery schools can be explained by two developments: firstly, "care" has become the norm in French schools and, secondly, professional roles and teaching jobs are ascribed along a gendered hierarchy. Then I will focus on the hurdles young women face when they enter the teaching profession and how balancing work and family is for them tantamount to "squaring the circle". I will explain how the family environment strongly pressures women into "putting family first". Finally, I will explore how women try to solve this normative dilemma linked to their working lives. I will turn to the mechanisms that underlie their choices in the context of the general hostility of the work sphere towards women and the internal institutional mechanisms that operate in schools.

This research exploits both the statistical data published yearly by the French Ministry of Education and several surveys that were conducted to confront such large scale data to qualitative findings. Questionnaires were administered as parts of different studies to 71 students preparing for a Master's Degree at the IUFM (University Institute for Teacher Training) in Rouen, to 338 teachers in the Basse Normandie district, and to 1576 teachers in the region of Normandy. In order to supply a set of qualitative data, observations were carried out in 6 nursery schools and 23 teachers were interviewed in the Basse Normandie district.

\section{Care as Norm When Working in a School}

Nursery schools do not offer enough teaching positions to cover the placement preferences of young female 
teachers. This trend is continuous and starts even before female teachers receive their training. The findings of a study conducted on an exhaustive sample of 71 candidates (only 6 men for 65 women) preparing a Master's degree in Elementary Education in 2011 clearly show the strong preference of women for teaching at nursery school level. The age of the pupils is a discriminating factor, since only 2 women would have preferred to teach pupils in their early teens, while 16 rank nursery school as their first choice. As a second choice, they prefer to teach Stage 2 pupils, i.e., 5-to-8 year olds (Note 1).

Among the reasons given to explain their preferences, the young women say they feel more comfortable with young children. "I'd feel more comfortable teaching elementary schools kids than with secondary school ones"; "I like the interaction with younger children, I don't feel comfortable around teenagers"; "I'd rather teach in a primary school, rather than any another level, it's the age group I like best, that I spend more time with outside school, and that I feel comfortable around". This argument openly questions the way future female teachers have been so firmly convinced that their place and their role lay first and foremost with very young children. Conversely, men would rather teach older Stage 3 pupils. Other men are turned off from teaching younger pupils or from teaching altogether, as the institution itself does not particularly welcome men's choice to teach young children. For teachers to feel legitimate, they need to feel comfortable in their choices. Yet, both parents' and school inspectors' expectations will further reinforce teachers' apprehensive attitudes even before they enter the teaching profession.

This type of sexual division of labor seems to run through all the divisions of the educational system, from nursery school all the way to university. The school system is no exception to the social rule that organizes work across a hierarchical ranking based on criteria unrelated to the real content of the work (Imbert \& Kergoat, 1992). This long-established gendered division of social roles is nowhere more striking than in nursery schools. This particular segment of the school system best illustrates a pervading ambivalence in the professional field of teaching. The useful role nursery schools play comes repeatedly under attack despite the use of active teaching methods which have proved crucial for disadvantaged children. Nursery schools are also fertile grounds for all types of stereotypes, fostering the social reproduction of gendered stereotypes in particular. On average, more than $90 \%$ (Note 2) of women of nursery school teachers are women, confirming the fact that women are confined to the traditional role of caring for young children. The expectations of parents and colleagues are so pressing that they make it hard to break away from that traditional role.

“Many parents ask you if you have children yourself, and if you don't have any, you don't know anything about children. I realized that if you want to be considered a good teacher, you'd better answer in the positive. The mothers of some pupils consider younger colleagues less worthy of being teachers if they're not mothers themselves, even though it's got nothing to do with teaching. Personally, I think that quite a lot of women think that school is just an extension of the work they do at home, that it's all the same" (Note 3).

Working in nursery schools doesn't seem to be considered as "real work" but rather as "under-employment" or "bogus" work, as if the complexity of the teaching activity from nursery school to university could be assessed by some kind of "natural law". The seriousness and legitimacy of teachers' work in nursery schools is not taken for granted, when it is not altogether questioned, and even more so when everything seems to contribute to blurring the distinction between the education within the family and the professional skills and expertise supplied by well qualified teachers. Women teachers in nursery schools are not considered highly qualified professionals nor does society fully recognize their significant educational role. On the contrary they suffer from their mother status and of the maternal role women play in the family, which always has a knock-on effect wherever women work. The gradual value of teaching is negatively correlated to the age group being taught, and teaching two year olds is arbitrarily seen as inferior to teaching primary school pupils, which is seen as inferior to teaching secondary school pupils and then university students, or so the depreciating value judgment goes.

Obvious proof of such an insidious ranking can be found in a case that caused quite a stir in France. Following an inspection, a male nursery school teacher received a thoroughly negative assessment report. This male teacher was teaching two-year olds, that is to say at the lowest rung in the French school system's hierarchy. The inspector considered it "abnormal" for a man to "work so little", i.e., "to look after young children". We are meant to understand that women teachers' inspection reports should sound less disparaging, since teaching young children is considered a woman's job, a potential mother's job. On the other hand, it is inconceivable that a man's job should be to "fulfill a mother's role. The scandal was no accident. This teacher had spent his entire career teaching in nursery schools and had even specialized in training nursery school teachers. Such a male teacher's career is rare and disrupts the well-established gender divisions in the school system. Women are a priori assigned to teach younger age groups even though their training was as demanding, but it seems that men could be put to better use. The real content of the work and of the effective activity is not appreciated. There is a 
double negation here as Laura Lee Downs (2002) shows when she reports that bosses described women's work as involving a high level of specialization but did not assimilate it to men's work. Repetitive work had to be done by women. In our case, the school inspector considered that working in a nursery school is a woman's job, since it can only be considered work if it is done by a woman, thus ignoring the increased professionalization of child pedagogy which has long been championed by various organizations and their publications.

In the inspector's view, a man working in a nursery school was committing serious professional misconduct and therefore should be sanctioned (the inspection report was thoroughly negative). The teacher was committing a "male faux pas", expressing an inappropriate masculine "taste" in the social sense that Bourdieu attributed to the term. There seems to be little room left for atypical male careers between male domination and an undervalued job for which "all it takes is to be a mother".

\section{Squaring the Circle}

A digression on the socialization within the family and women's expected role as spouses may help shed some light on the hurdles female teachers have to face when starting their working life. In their interviews, women represent their motivation for teaching as essentially linked to relating to children (65\% of the women versus $47 \%$ of men), while men more frequently referred to the influence of their family or friends and acquaintances ( $30 \%$ versus $18 \%$ of women).

Yet personal preferences do not show that early childhood systemically appeals to women and there are plenty of examples of career choices constrained by the demands of family life. Interestingly, we found that choosing to work in a nursery school seems correlated to the occupational category of the teachers' fathers first, especially if fathers were self-employed, then to the occupational category of their partner (Note 4). On equal qualifications, most female teachers choose to teach in nursery schools over elementary schools, and this goes for both private and public schools. In nursery schools, the daughters of craftsmen, shopkeepers, or business owners (20.7\%) outnumber all other categories, be it in public or private schools. Then, as regards marital status, the daughters and wives of farmers are over-represented in private nursery schools, just as the daughters and wives of craftsmen, shopkeepers or business owners are overrepresented in both private and public nursery schools. So it seems that the family environment plays a role in why women "choose" to turn towards lower-ranking teaching positions that fit the traditional assignment of gender roles.

Being employed as a teacher also fits the needs of the household and seems convenient for everyone. "Honestly, we found quite a nice house. It's a big snug house, as close as possible to the farm. Being a teacher helps a lot, banks don't make a fuss. You just have to ask for a loan, and it's a done deal .... But it's in the country, which is nice when you're raising kids. We can't complain, good quality of life. I work in a public nursery school, I'm in charge of the 4 and 5 year-olds. I don't like it that much. I prefer older children, but here's the good thing: as my son is still quite young, I was assigned to a school that's really close to home. Could be worse, it's a small rural school, much quieter than a city school" (Note 5).

In addition to all these practical reasons, the "added bonus" is that women teachers hold a less important or a clearly secondary position in the couple when their spouse is an executive, as they contribute less to the household income and their schedule is a perfect fit for child care. Many teachers' husbands or partners have a better paying job (in nursery schools, 17\% of the husbands hold an executive position in the public sector, and 19\% in the private sector.) The expectations associated to their marital status further incite women to conform to their role of mothers-spouses-educators: "Because I often hear younger colleagues say-before they even know which form, which children they are going to teach - they say "Yeah, fine!, but how am I going to manage with my kids, my husband works twenty miles away, and I'm having my house built" (Note 6).

Survey findings also clearly showed that family life is fundamental for women teachers. The role they play at home is central, and they seem to have been prepared to play such a role since childhood. As children, women teachers were systematically involved in household chores ( $96 \%$ for $86 \%$ of male teachers). And in their current daily life, they are always in charge of preparing meals (74\%), while male teachers only do it from time to time $(56 \%)$. Women also attend parent-teacher meetings more often (96\% when $48 \%$ of men do). They also are in charge of the children's daily grooming ( $74 \%$ for $11 \%$ ), of buying their clothes ( $90 \%$ for $1 \%)$, their toys ( $57 \%$ for $14 \%$ ), their books ( $72 \%$ for $25 \%$ ) and of renewing their subscriptions ( $71 \%$ for $28 \%$ ).

The distinction between men and women's hobbies clearly mirrors the gendered division of roles at play in the society they live in. Outdoor activities take up more of male teachers' free time (62\% compared to $48 \%)$, sports clubs ranking first (for $32 \%$ of men teachers compared to $16 \%$ of women teachers), while reading is women teachers' favorite pastime ( $45 \%$ compared to $23 \%$ ). Home computing is mostly a man's hobby ( $12 \%$ compared to $3 \%$ ). For women teachers, family is the main social meeting place, even during leisure activities ( $29 \%$ of 
women teachers meet their family relatives there, compared to only $17 \%$ of men teachers). On the other hand, men teachers' social network is more diverse, since they meet more different people (39\% compared to $28 \%$ )

Women teachers seem also less career-driven. While $41 \%$ of men teachers can picture themselves at the head of a school, $71 \%$ of women teachers consider it incompatible with their current family life. Besides, $23 \%$ of women teachers have had to resort to part-time compared to only $5 \%$ of men. Men tend to have higher career prospects and $26 \%$ of them would have liked to work in higher education, compared to only $15 \%$ of women.

Women's career development is more often interrupted by part time and once they've entered the profession, women do not further their career. For primary and secondary school teachers having and raising children is not an issue. This is hardly the case for ambitious women in very competitive jobs, such as the women biologists studied by Catherine Marry and Irène Jonas (2005). For them, maternity and career may clash, which is not the case for women teachers since their role as mothers is part and parcel of their career "choice".

\section{Solving the Normative Dilemma of Employment}

As more and more women turn toward teaching, the limits of an allegedly "tailor-made" job start to show. The traps laid for women by a teaching career may be seen to resemble the function of a multiple stroke engine. Firstly, since female student teachers were usually very good pupils with excellent school records (good at demanding educational paths, graduating high school with honors), they could have proved more ambitious, were it not for the self-deprecation and lack of confidence that characterizes girls' socialization (Baudelot \& Establet, 1992).

Secondly, the job market seems to be telling girls that they could not choose a better job. It is at the same time true that teaching has been more welcoming for women than most careers and has helped with their emancipation. And since the world of work is still quite hostile to women, teaching has become a fallback solution. Their families are less supportive of their careers than for boys and as a result girls are granted more autonomy which does not mean more leeway. This shows the lesser social importance of their future job, since their future job will always be considered of secondary importance in their case (Gouyon \& Guérin, 2006). Families have also their girls' future all mapped out. When contemplating their girl's future, parents are mainly concerned by her future family happiness, which could account for why competitive science studies are less sought after by girls. The opposite is true for boys. A boy's professional success is a top priority.

"Boys are not allowed to make their own choices at school, they seem more socially constrained by family pressure. They tend to choose money-making jobs, but when you dig deeper they also say 'When I'm a family man, I'll need to be the bread-winner, I'll need to provide for my family.' I'm stunned when I hear that. Girls don't see things that way. That being said, in high school, girls often make choices just to stay with their boyfriend, which means they are bound to take a subservient position in the couple" (Note 7).

One of the pitfalls that awaits women teachers is that their job will be considered "a great chance" for household balance. If female teachers working in elementary schools can more easily fulfill the role of the ideal wife without making too many professional sacrifices, it proves much harder for high-ranking secondary school professors who often give up on academic research and restrict their professional activity to teaching as Marlaine Cacouault's study on teachers' biographies showed. The fact that women focus on their family, their children and their spouse ("Cinderella complex", 2002) contributes to their spouse's professional success (Gadéa \& Marry, 2000).

Another pitfall comes later on in the course of their career. Just as going into teaching is a fallback position for many bright students (Note 7), choosing to teach at elementary level is another fallback position when women give up the idea of teaching in secondary schools or when they refuse to take on more responsibilities such as becoming head of a school. Most women teachers seem stuck to the unequal initial positions and suffer from a lack of recognition as a result. The career trajectory of female biology students illustrates such a process. While a growing number of female students choose to study biology (the only "exact" science that is no longer a male student stronghold), this has not resulted in more female biology teachers and they are far less likely to become biology professors or to manage a lab. More generally, even if the proportion of women teachers has long been growing steadily, women's careers are still not on a par with men's.

A growing number of women see teaching as a way of "squaring the circle", a way of conforming to their role as mothers and ideal spouses of their successful husbands while trying nevertheless to secure the greatest possible reward from the degrees and qualifications they got in a still segregated profession. Choosing a teaching career is an ambiguous answer to the question raised by Duru-Bellat (1990) "Career counselling for girls: For which social roles?" Once they have become teachers, women may feel deceived by the way positions are assigned in 
the school system's hierarchy. Solving the dilemma between conformism and emancipation is not an easy feat. This may be the reason why teaching appears as the least bad option when compared to many other feminized professions.

\section{Conclusion}

The range of professions open to women is not that broad. Out of 455 professions, only about twenty comprise $45 \%$ of all working women. Women are overall mostly found in two occupational categories: employees (76\%) and intermediary jobs (48\%). Still most executives are men, but more specifically, teaching and scientific professions is the only category that counts $54 \%$ of women (Pfefferkorn, 2007). Moreover, women's work is very often related to care work, since it is thought to require skills that women "naturally' have. As teaching borders on care work (Molinier, 2006) women do not have to choose between career and family, which does not make the activity of women teachers less ambiguous, as educational work is still markedly divided along gender lines in French schools.

If teacher training aims at fostering equal opportunities in schools, it should help overcome initial stereotypes and work out ways to make the contribution of female teachers more legitimate. Some trade union activists champion the idea of renaming nursery schools "first schools". Such a change in name could help change representations: women would no longer be seen as "naturally" predisposed to specialize in pre-school work and working in "first school" would appear more gender-neutral. It would finally help establish a clear-cut distinction between the biological function of motherly care and the social function of schooling. This distinction is key if schools are to break away from family patterns and teachers are to be seen as real professionals. If gender parity in schools is not just words but a main objective, it is crucial to state and declare publicly that schools are not meant to perpetuate the gendered social roles still going strong at home and it could offer youngsters more diverse professional careers.

\section{Data Collection}

Our database is composed of the findings of two main surveys (Questionnaires were administered to 71 students preparing for a Master's Degree at the Rouen University Institute for Teacher Training (IUFM); observations were carried out in 6 nursery schools and 23 teachers were interviewed in Basse Normandie, via a life-course approach). These quantitative and qualitative data are examined against the statistical data published yearly by the French Ministry of Education, and against some results from two extensive original surveys (Questionnaires were administered to 338 teachers and then to 1576 teachers in Normandy).

\section{References}

Baudelot, C., \& Establet, R. (1992). Allez les filles! Paris: Seuil.

Cacouault-Bitaud, M. (2007). Professeurs ... mais femmes. Carrières et vie privée des enseignantes du secondaire au XXe siècle. Paris: La Découverte.

Delavault, H., Boukhobza, N., Hermann, C., \& Konrad, C. (2002). Les enseignantes-chercheuses à l'université: Demain la parité ? Paris: L'Harmattan.

Devineau, S. (2006). "L'école pour les femmes : Rapports sexués aux savoirs professionnels chez les candidats à l'IUFM". L'Orientation Scolaire et Professionnelle, 35(1), 29-55. http://dx.doi.org/10.4000/osp.883

Devineau, S. (2012). Le Genre à l'école des enseignantes. Embûches de la mixité, et leviers de la parité (Coll. Logiques sociales). L'Harmattan.

Duru-Bellat, M. (1990). L'école des filles. Quelle formation pour quels rôles sociaux. Paris : l'Harmattan.

Gadéa, C., \& Marry, C. (2000). Les pères qui gagnent, descendance et réussite professionnelle des ingénieurs. Travail, Genre et Société, 3, 109-135. http://dx.doi.org/10.3917/tgs.003.0109

Gouyon, M., \& Guérin, S. (2006). L'implication des parents dans la scolarité des filles et des garçons: Des intentions à la pratique. Economie et statistique, 398-399, 59-84. http://dx.doi.org/10.3406/estat.2006.7117

Lee, D. L. (2002). L'inégalité à la chaîne. La division sexuée du travail dans l'industrie métallurgique en France et en Angleterre. $1^{e r e}$ édition en anglais, 1995, Coll. L'évolution de l'humanité. Paris: Albin Michel.

Marry, C., \& Jonas, I. (2005). Chercheuses entre deux passions. L'exemple des biologistes. Travail, Genre et Sociétés, 14, 69-88. http://dx.doi.org/10.3917/tgs.014.0069

Molinier, P. (2006). Lecare: Ambivalences et indécences. Revue Sciences Humaines, 177.

Pfefferkorn, R. (2007). Inégalités et rapports sociaux. In Rapports de classes, rapports de sexes. Paris: La Dispute. 


\section{Notes}

Note 1 . French nursery and elementary schools are divided into 3 stages. Stage 1 comprises the first three years of nursery school (2 to 5-year olds). Stage 2 comprises the last year in nursery school and the first two years of elementary school (5 to 7-year olds) and Stage 3 corresponds to the last three years of elementary school (8 to 10 year-olds).

Note 2. Procoppe (2002), Primary school teachers in public schools for the year 2000 (News Bulletin note). In 1999, men made up 6\% of the 78400 nursery school teachers; "Primary school teachers in public schools on September 1st 1999 ", Ministry of National Education, News Bulletin, 01-19, mai 2001.

Note 3. Female primary school teacher, 40 years old, 5 children; union representative at national level, political activist; both her parents are bank employees.

Note 4. Total from nursery school to university, public and private combined: $11,8 \%$ of farmers and $16,2 \%$ of craftsmen and shopkeepers

Note 5. Female elementary school teacher, 29 years old, working in a public nursery school; father railway worker, mother nurse, spouse farmer.

Note 6 . Female primary school teacher, 40 years old, 5 children; union representative at national level, political activist; both her parents are bank employees.

Note 7. Woman, 35 years old, History and Geography teacher in public high school, union member, father chemist, mother primary school teacher.

Note 8. Christine Fontanini $(2008,2009)$ in her survey showed that teaching does not rank first among high-achieving school leavers; it ranks long behind medicine studies.

\section{Copyrights}

Copyright for this article is retained by the author(s), with first publication rights granted to the journal.

This is an open-access article distributed under the terms and conditions of the Creative Commons Attribution license (http://creativecommons.org/licenses/by/3.0/). 